Creative Commons User Licence: CC BY-NC-ND

Abstracted by: EBSCOhost, Electronic Journals Service (EJS),

Google Scholar, Directory of Open Access Journals (DOAJ),

Journal Seek, Scientific Commons, and

Food and Agricultural Organization (FAO)
Journal of Agricultural Extension

Vol.19 (1) June, 2015

ISSN 24086851

http://journal.aesonnigeria.org

http://www.ajol.info/index.php/jae

http://dx.doi.org/10.4314.jae.v19i1.8

\title{
Effect of Personality Types of Extension Personnel on their Job Performance in Rivers State Agricultural Development Programme.
}

\author{
M. C. Ijeoma ${ }^{1}$, O. M. Adesope ${ }^{2}$ \\ ${ }^{1}$ Department of Agricultural Extension and Rural Development, \\ University of Ibadan, Ibadan, Oyo State \\ ${ }^{2}$ Department of Agricultural Economics and Extension, \\ University of Port Harcourt, Choba, Rivers State
}

Abstract

This research examined the effect of personality types of extension personnel on their job performance in Rivers State Agricultural Development Programme (RISADEP). Specifically, the study described the socio-demographic characteristics of respondents, identified the individual personality types of extension personnel in RISADEP, ascertained the job performance of extension personnel; determined whether a relationship exist between job performance and personality type of extension personnel and whether Socio-demographic characteristics affect job performance of extension personnel. Data collection was with the aid of a structured questionnaire administered to 63 extension personnel which was randomly selected from six area offices of which only 57 was useable for analysis. Data were analyzed using frequency, percentage and correlation analysis. The findings of the study indicated that the level of job performance for each of the extension personnel sampled was rated above average with a mean performance of 71.39. The correlation analysis result showed that there is a significant relationship between job performance and personality type of extension personnel of 0.411 at 0.01 level of significance, with more of the extension personnel with ESFJ (Extroverted feeling with sensing) (29.82\%) personality type followed by ISFJ (Introverted sensing with feeling) (19.3\%) and ENFJ (Extroverted feeling with intuiting) (12.28), ENFP (Extroverted intuiting with feeling), ENTP (Extroverted intuiting with thinking), ESTJ (Extroverted thinking with sensing) with (8.8\%). Findings also revealed that socio-demographic characteristics do not significantly affect job performance of extension personnel except experience which had a positive and significant correlation of 0.276 at 0.05level of significance. It is therefore recommended among others that a personality test be conducted during recruitment of personnel to ensure that personnel with the right personality are employed and a constant appraisal of extension personnel job performance to make sure that they are up and doing.

Key words: Extension personnel, Personality type and Job performance 
Creative Commons User Licence: CC BY-NC-ND

Abstracted by: EBSCOhost, Electronic Journals Service (EJS),

Google Scholar, Directory of Open Access Journals (DOAJ),

Journal Seek, Scientific Commons, and

Food and Agricultural Organization (FAO)
Journal of Agricultural Extension

Vol.19 (1) June, 2015

ISSN 24086851

http://journal.aesonnigeria.org

http://www.ajol.info/index.php/jae

\section{Introduction}

The importance of agricultural extension in agricultural development is widely acknowledged, particularly in developing countries such as Nigeria where agriculture is the main source of livelihood of the people. The Agricultural Development Programmes (ADPs) are currently responsible for carrying out the bulk of agricultural extension activities in Nigeria. The ADPs are designed to improve the agricultural productivity, income, and general well being of the small scale farmer who is the centre-piece of all agricultural development efforts in Nigeria (FGN, 1997). The activities of the ADPs are carried out through extension services which are done by trained extension personnel (agents). The mission of the Extension Service is to provide research-based information, educational programs, and technology transfer focused on the issues and needs of the people, enabling them to make informed decisions about their economic, social and cultural wellbeing.

The success of ADPs depend on a large scale adoption of improved agricultural technologies by farmers and brilliant performance of frontline extension workers, that is, extension agents, block extension agents, and block extension supervisors saddled with this responsibility (Akinsorotan and Adah, 1997).

The job performance of extension workers in ADPs is a great concern to agricultural administrators, policy makers, research centres and development practitioners. Subsequently, appraising the job performance of these extension workers will provide policy makers, programme administrators, and development practitioners at all levels with relevant information they need for improvement and future planning (Ekumankama \& Anyanwu, 2007).

The performance of an individual on any job endeavour is to a large extent influenced by his personality. This is in line with the fact that human behaviour is a function of his environment and/or gene. The implication of this is that the way an individual behaves depends on his genetic make-up which relates to his personality. In this case, an extension personnel who performs creditably on his job could have been influenced by his natural disposition. These extension 
Creative Commons User Licence: CC BY-NC-ND

Abstracted by: EBSCOhost, Electronic Journals Service (EJS),

Google Scholar, Directory of Open Access Journals (DOAJ),

Journal Seek, Scientific Commons, and

Food and Agricultural Organization (FAO)
Journal of Agricultural Extension

Vol.19 (1) June, 2015

ISSN 24086851

http://journal.aesonnigeria.org

http://www.ajol.info/index.php/iae

personnel as do all individuals have, personality types or characteristics that distinguish them from each other; these characteristics may make an extension officer suitable for working with the rural farmers or not. It is therefore important to understand the importance of different personality types contributing to a person's performance when working with the rural farmers.

An investigation into the personality type of extension personnel in Rivers State ADP is worth considering because of the fact that an individual's attitude towards others is a function of his personality. It is therefore important to identify those personality type(s) that will enhance effective extension service delivery at all levels of extension work, as personality has been found to account for unique variance in performance (Hough, 1992)

Research related to personality has recently clarified the utility (usefulness) of using personality variables for prediction of job performance. Hough (1992) has demonstrated that personality constructs are indeed associated with job performance, some traits such as conscientiousness predicting success across jobs. Barrick, Mount, and Strauss (1993) found autonomous goal setting, and a lesser extent goal commitment, to mediate relationships between Conscientiousness and two measures of job proficiency-supervisory ratings of job performance and sales representatives. Gallantly (1996) found goals and expectancy to mediate relationships between conscientiousness and performance on arithmetic tasks. Meta-analysis has also shown repeatedly that personality measures can predict job performance fairly well under certain conditions (Salgado, 1997; Tett, et al, 1991). However, very little research has examined the mechanisms through which personality type influence job performance of extension personnel. This study therefore intends to address this

\section{Purpose of the Study}

The purpose of this study was to describe the relationship between personality type, demographic characteristics, and job performance of extension personnel in Rivers State ADP. Specific objectives of the study were to:

i. describe the socio-demographic characteristics of respondents. 
Creative Commons User Licence: CC BY-NC-ND

Abstracted by: EBSCOhost, Electronic Journals Service (EJS),

Google Scholar, Directory of Open Access Journals (DOAJ),

Journal Seek, Scientific Commons, and

Food and Agricultural Organization (FAO)
Journal of Agricultural Extension

Vol.19 (1) June, 2015

ISSN 24086851

http://journal.aesonnigeria.org

http://www.ajol.info/index.php/jae

ii. identify the individual personality types of extension personnel in Rivers State Agricultural Development Programme (ADP)

iii. ascertain the individual job performance of extension personnel.

iv. determine whether a relationship existed between job performance and personality type of extension personnel.

v. determine whether Socio-demographic characteristics affect job performance of extension personnel

\section{Methodology}

The study was carried out in Rivers State Agricultural Development Programme (ADP). Rivers State is one of the 36 states of Nigeria. Its capital is Port Harcourt and it has 23 Local Government Areas. It is bounded on the East by Akwa Ibom, to the South by the Atlantic Ocean, to the North by the Anambra, Imo and Abia State, and to the West by the Bayelsa and Delta State. The inland part of Rivers State consists of tropical rainforest; towards the coast the typical river delta environment features many mangrove swamps. It has a population of about three million people and occupies an area of 21,850 sq. Km. With two third of it in the Niger Delta geographical terrain. The dominant ethnic groups are Ijaw, Ikwere, Etche, Ogoni and Ogba/Egbema. Agriculture is the main occupation of the people, and the agricultural policy of the state government is anchored on food production. The state has three Agricultural Zones namely Ahoada, Degema and Eleme Zones, with nine area offices, three each of the three zones. Multi-stage simple random sampling technique was adopted to select six area offices and out of the nine area offices and 63 respondents were randomly selected for the research at different levels of the selection. I.e. the 4-personnel from the HQs, 1-ZM, 5-AEO, 10-BES, and 43-EAs, out of which only 57 was good for analysis.

A structured questionnaire was employed for data collection. The questionnaire was adopted items on personality type indicator and job performance scale. Job performance of respondents was determined using Job Performance Scale (JPS), which is a set of 21 questions on four point Likert Scale as adopted from Agumagu; Personality Type Indicator (PTI) was used to identify the personality type of respondents. The PTI is a pen and pencil test on measuring personality and it 
Creative Commons User Licence: CC BY-NC-ND

Abstracted by: EBSCOhost, Electronic Journals Service (EJS),

Google Scholar, Directory of Open Access Journals (DOAJ),

Journal Seek, Scientific Commons, and

Food and Agricultural Organization (FAO)
Journal of Agricultural Extension

Vol.19 (1) June, 2015

ISSN 24086851

http://journal.aesonnigeria.org http://www.ajol.info/index.php/iae

is a set of 72question with each question pointing to a particular preference on a person's personality, adopted from Meyer-Briggs Type Indicator, so the respondents were rated according to their preferences.

Table 1: Job description of extension personnel in Rivers State Agricultural Development Programme

\begin{tabular}{llcc}
\hline S/N & Designation/Job description & Number of Personnel & $\begin{array}{c}\text { Area of } \\
\text { Operation }\end{array}$ \\
\hline 1 & Director Extension Services (DES) & 1 & HQs \\
2 & Deputy Director Extension Services & 1 & HQs \\
& (DDESS) & 1 & HQs \\
3 & Head Women in Agriculture (HWIA) & 1 & HQs \\
4 & Chief Communication Officer (CCO) & 3 & Field \\
5 & Zonal Managers (ZM) & 9 & Field \\
6 & Area Extension Officers (AEO) & 24 & Field \\
7 & Block Extension Supervisors'(BEA) & 9 & Field \\
8 & Block Extension Agents'(BEA) & 71 & Field \\
9 & Extension Agents (EA's) & 120 & \\
\hline
\end{tabular}

Source: Rivers State Agricultural Development Project (2010)

\section{Results and Discussion}

\section{Socio-Demographic Characteristics of Respondents}

Table 2 shows that majority of the respondents are between the age range of $51(47.40 \%)$ and 55 years (86.0\%), with $86.00 \%$ of the extension personnel as males. This shows that there are more male involved in extension work in Rivers State ADP than the female counterparts and this supports FAO (1988), that field personnel tend to be all male. The study further reveals that majority (59.60\%) of extension personnel have a house hold size of 7 to 11 persons. About $33 \%$ hold the Higher National Diploma as their highest educational qualification. 
Creative Commons User Licence: CC BY-NC-ND

Abstracted by: EBSCOhost, Electronic Journals Service (EJS),

Google Scholar, Directory of Open Access Journals (DOAJ),

Journal Seek, Scientific Commons, and

Food and Agricultural Organization (FAO)
Journal of Agricultural Extension

Vol.19 (1) June, 2015

ISSN 24086851

http://journal.aesonnigeria.org

http://www.ajol.info/index.php/jae

About half of the extension personnel in RISADEP (50.90\%) had worked between 13 to 24 years with as the last recruitment. This implies that for the past 13yrs there has been no employment or recruitment of extension staff in RISADEP. This have major setback for extension service delivery in RISADEP as the vigor required for may be lacking. There is need for recruitment of staff at RISADEP, as this was also visible at the field as only about 40 EA's were covering 284 circles.

Table 2: Distribution of respondent according to socio-demographic characteristics

\begin{tabular}{llll}
\hline Variable & & Percentage (\%) & Mean \\
\hline Age: & $41-45$ & 12.30 & 50.9 \\
& $46-50$ & 28.10 & \\
Sex: & $51-55$ & 47.40 & \\
& $56-60$ & 12.30 & \\
House hold & Male & 86.00 & 7.4 \\
size: & Female & 14.00 & \\
& $2-6$ & 33.30 & \\
Years in & $7-11$ & 59.60 & \\
Service: & $12-16$ & 7.00 & \\
Highest & $13-24$ & 50.90 & \\
Educational & $25-36$ & 49.10 & \\
Qualification & WASC (O' Level) & 3.50 & \\
& OND & 19.30 & \\
& NCE & 3.50 & \\
& HND & 33.30 & \\
Job position & Bachelor Degree & 22.80 & \\
& PGD & 7.00 & \\
& Masters Degree & 10.50 & \\
& HWIA & 1.80 & \\
& ZM & 1.80 & \\
& AEO & 8.80 & \\
& BES & 17.50 & \\
& EA's & & \\
& & & \\
& & &
\end{tabular}

Source: Field survey, 2011 
Creative Commons User Licence: CC BY-NC-ND

Abstracted by: EBSCOhost, Electronic Journals Service (EJS),

Google Scholar, Directory of Open Access Journals (DOAJ),

Journal Seek, Scientific Commons, and

Food and Agricultural Organization (FAO)
Journal of Agricultural Extension

Vol.19 (1) June, 2015

ISSN 24086851

http://journal.aesonnigeria.org

http://www.ajol.info/index.php/jae

\section{Personality Type of Extension Personnel in RISADEP}

Table 3: Personality type of extension personnel using the Myer-Briggs Type Indicator .

\begin{tabular}{llc}
\hline S/n & Personality Type & Percentage (\%) \\
\hline 1 & ENFJ & 12.3 \\
2 & ENFP & 8.8 \\
3 & ENTJ & 0.0 \\
4 & ENTP & 8.8 \\
5 & ESFJ & 29.8 \\
6 & ESFP & 0.0 \\
7 & ESTJ & 8.8 \\
8 & ESTP & 0.0 \\
9 & INFJ & 3.5 \\
10 & INFP & 3.5 \\
11 & INTJ & 0.0 \\
12 & INTP & 0.0 \\
13 & ISFJ & 19.3 \\
14 & ISFP & 0.0 \\
15 & ISTJ & 3.5 \\
16 & ISTP & 1.8 \\
\hline Total & & 100.00 \\
\hline
\end{tabular}

Source: Field survey, 2011

Table 3 presents the Myers-Briggs personality types of extension agents in RISADEP. The personality type most exhibited by the extension agents was ESFJ (Extrovertedj feeling with sensing) (29.8\%) which was followed by ISFJ (Introverted sensing with feeling) (19.3\%) and ENFJ (Extroverted feeling with intuiting) (12.28), ENFP (Extroverted intuiting with feeling), ENTP (Extroverted intuiting with thinking), ESTJ (Extroverted thinking with sensing) with (8.8\%), INFJ (Introverted intuiting with feeling), INFP (Introverted feeling with intuiting), ISTJ (Introverted sensing with thinking) with (3.5\%) and ISTP (Introverted thinking with sensing) $(1.8 \%)$. Some personality types are not exhibited by the extension personnel in RISADEP such as ENTJ (Extroverted thinking with intuiting), ESFP (Extroverted sensing with feeling), ESTP (Extroverted sensing with thinking), INTJ (Introverted intuiting with thinking), INTP (Introverted thinking with intuiting) and ISFP (Introverted feeling with sensing). 
Creative Commons User Licence: CC BY-NC-ND

Abstracted by: EBSCOhost, Electronic Journals Service (EJS),

Google Scholar, Directory of Open Access Journals (DOAJ),

Journal Seek, Scientific Commons, and

Food and Agricultural Organization (FAO)
Journal of Agricultural Extension

Vol.19 (1) June, 2015

ISSN 24086851

http://journal.aesonnigeria.org

http://www.ajol.info/index.php/iae

\section{Individual Job Performance of Extension Personnel in ADP}

Table 4: Level of job performance of extension personnel in ADP

\begin{tabular}{lcc}
\hline Level & Percentage $(\%)$ & Mean \\
\hline Low $(57-65)$ & 26.3 & 71.39 \\
Moderate (66-75) & 36.8 & \\
High $(76-85)$ & 36.8 & \\
\hline Total & 100 & \\
\hline
\end{tabular}

Source: Field survey, 2011

The overall performance evaluation scores of extension personnel where clustered between 66-77 and 76-85 having 36.80percentage of respondents respectively, with the grand mean for job performance of the Extension personnel in Rivers State ADP as 71.39. Table 4 represents the ranges of Performance Evaluation Instrument Scores. It could be inferred from these findings that the performance of the extension personnel was rated above average. This finding is in agreement with the results from similar study by Ekumankama and Anyanwu (2007) that reported high performance of extension staff in Akwa Ibom State of Nigeria.

\section{Relationship between job performance and personality type of extension personnel}

Table 5: Relationship between Job performance and personality

\begin{tabular}{lccc}
\hline Variable & $\mathbf{N}$ & $D f$ & r-value \\
\hline Job performance & 57 & 55 & $0.411^{* *}$
\end{tabular}

** $\mathbf{P}<\mathbf{0 . 0 1}, d f=2,(2-$ tailed $)$

Job performance was found to be positively correlated with personality type and significant (Table 5). This implies that an extension agent's job performance is attributed to his personality type. This contradicts John et.al (2007) that an agents job performance cannot be attributed to his personality, but agrees with Mahlamaki (2010) on his study on the influence of personality on job performance of key account managers. 
Creative Commons User Licence: CC BY-NC-ND

Abstracted by: EBSCOhost, Electronic Journals Service (EJS),

Google Scholar, Directory of Open Access Journals (DOAJ),

Journal Seek, Scientific Commons, and

Food and Agricultural Organization (FAO)
Journal of Agricultural Extension

Vol.19 (1) June, 2015

ISSN 24086851

http://journal.aesonnigeria.org

http://www.ajol.info/index.php/iae

\section{Socio-demographic Characteristics and Job Performance of Extension Personnel.}

Table 6: Test of relationship between socio-demographic characteristics and job performance

\begin{tabular}{lc}
\hline Variable & r-values \\
\hline Age & 0.110 \\
Sex & -0.152 \\
Marital status & 0.038 \\
House hold size & 0.023 \\
Qualification & 0.034 \\
Experience & $0.276^{*}$ \\
Job position & 0.010 \\
Income & 0.026 \\
\hline$*=$ correlation is significant at the 0.05level $(2-$ tailed $)$ & \\
$d f=\mathrm{N}-2=57-2=55$ &
\end{tabular}

Table 6 shows that socio-demographic characteristics do not affect job performance except experience which was found to be positively correlated with job performance and significant at 0.05level of significance. It could be inferred that personnel who have worked for a longer time, performs better than new recruits as they have fully understand the rudiments of extension service delivery. This is in consonance with John et.al (2007) on their work in factors influencing individual job performance of extension agents in the Mississippi State University Extension Service. However, Sex, was found to be negative correlated with job performance, which means that it has inverse relationship with job performance.

\section{Conclusion}

The majority of agents in this study belonged to 4 of the 16 personality types: ISTJ, ISFJ, ESTJ, and ESFJ, which were similar to the findings of other studies (John et.al, 2007 \& Jenkins, 2001). While no personality type should be viewed as the best, perhaps personality type can be used as a tool in which agents could be selected based on their individual strengths and weaknesses and how they could be used in order to be more effective employees. Personality is indeed a veritable tool for accessing a personnel job performance. This study has also shown that the performance of extension personnel in RISADEP is above average. 
Creative Commons User Licence: CC BY-NC-ND

Abstracted by: EBSCOhost, Electronic Journals Service (EJS),

Google Scholar, Directory of Open Access Journals (DOAJ),

Journal Seek, Scientific Commons, and

Food and Agricultural Organization (FAO)
Journal of Agricultural Extension

Vol.19 (1) June, 2015

ISSN 24086851

http://journal.aesonnigeria.org

http://www.ajol.info/index.php/iae

The following recommendations are made:

1. Constant appraisal of extension personnel job performance to make sure they are performing well.

2. A personality test should be conducted during recruitment of personnel to ensure that personnel with the right personality are employed.

3. Women should be given more opportunity to serve as extension personnel. Hence, the need for more recruitment of women in RISADEP.

\subsection{Policy Implications}

Personality has been regarded by many as something too mysteriously wonderful to be studied. It is also alleged that nobody knows perfectly enough about personality, like other disciplines it is subject to known orderly laws and principles. Based on the findings of this study, it is therefore concluded that personality type indeed has a great influence on job performance of extension personnel, with Extroverted Feeling with Sensing (ESFJ) found to be the best personality for extension personnel job performance, as these people (ESFJ) like harmony. They wear their hearts on their sleeves and excel in service occupations involving personal contact.

Some of these skills as embedded in the personality can also be acquired or strengthened with the appropriate training for effective extension delivery, which in turn reflects on the output of the farmers with increased production. It is therefore expedient, for policy makers in extension service delivery to make policies aimed to assist extension agents in the development and availability of such training.

\section{References}

Agricultural Development Project (2010), Job Description of Extension Personnel. Rivers State Agricultural Development Programme (RISADP), I-2

Agumagu, A. C. (1992). Determinants of Job Performance among Agricultural Extension Agents in Agricultural Development Projects in Rivers and Imo State of Nigeria. Ph.D. Thesis, Dept of Agric. Extension and Rural Development, University of Ibadan. 
Creative Commons User Licence: CC BY-NC-ND

Abstracted by: EBSCOhost, Electronic Journals Service (EJS),

Google Scholar, Directory of Open Access Journals (DOAJ),

Journal Seek, Scientific Commons, and

Food and Agricultural Organization (FAO)
Journal of Agricultural Extension

Vol.19 (1) June, 2015

ISSN 24086851

http://journal.aesonnigeria.org

http://www.ajol.info/index.php/iae

Akinsorotan, A.O., Adah, O.C. (1997). Determinants of job satisfaction of agricultural extension agents in Kogi State Agricultural Development Project, Nigeria, Journal of Agricultural extension, 1:28-33

Barrack, M. R., Mount, M. K., \& Strauss, J. P. (1993). Conscientiousness and performance of sales representatives: Test of the mediating effects of goal setting. Journal of Applied Psychology, 78:715-722.

Ekumankama O. O and Anyanwu A. C. (2007) Assessment of the job performance of extension staff in Akwa Ibom State of Nigeria, ASSET Series C (2007) 2 (1): 165-178.

Food and Agricultural Organisation (FAO). (1988). Guide on alternative Extension Approach, Food and Agricultural Organisation of the United Nations, pp72

Federal Government of Nigeria (FGN) (1997). Federal Republic of Nigeria (FGN) national position paper, In: Integrated agricultural production in Nigeria: Strategies and mechanisms for food security, Shaib, B., Adedipe, N. O., Aliyu, A. And Jir, M. M. (Eds.), Pp. 11-74, Proceedings of the National Workshop on Nigeria's Position at the World Food Summit.

Gallantly, I. R., (1996). Conscientiousness and task performance: Test of a cognitive process model. Journal of Applied Psychology, 81, 474-482.

Jenkins, J. H. (2001). Relationship between selected characteristics of county extension agents in Mississippi and their level of job performance. Mississippi State University, Mississippi State, Mississippi.

John L. L., Kirk A. S. (2007). Factors influencing individual job performance of extension agents in the Mississippi State University Extension Service. Proceedings of 2007 AAAE Research Conference, Volume 34

Mahlamaki, T. (2010), Influence of personality on the job performance of key Account Managers. Department of Industrial Management. Tampere University of Technology, Tampere, Finland. 
Creative Commons User Licence: CC BY-NC-ND

Abstracted by: EBSCOhost, Electronic Journals Service (EJS),

Google Scholar, Directory of Open Access Journals (DOAJ),

Journal Seek, Scientific Commons, and

Food and Agricultural Organization (FAO)
Journal of Agricultural Extension

Vol.19 (1) June, 2015

ISSN 24086851

http://journal.aesonnigeria.org

http://www.ajol.info/index.php/jae

Tett, R. P., Jackson, D. N., \& Rothstein, M. (1991). Personality measures as predictors of job performance: A meta-analytic review. Personnel Psychology, 44:703-742. 